Meta

Journal des tradlucteurs

Translators' Journal

\title{
Transliteration of English Proper Nouns into Arabic
}

\section{Yowell Y. Aziz}

Volume 28, numéro 1, mars 1983

La traduction dans le monde

Translation around the World

URI : https://id.erudit.org/iderudit/001931ar

DOI : https://doi.org/10.7202/001931ar

Aller au sommaire du numéro

Éditeur(s)

Les Presses de l'Université de Montréal

ISSN

0026-0452 (imprimé)

1492-1421 (numérique)

Découvrir la revue

\section{Citer cet article}

Aziz, Y. Y. (1983). Transliteration of English Proper Nouns into Arabic. Meta, 28(1), 70-84. https://doi.org/10.7202/001931ar d'utilisation que vous pouvez consulter en ligne.

https://apropos.erudit.org/fr/usagers/politique-dutilisation/ 


\section{TRANSLITERATION OF ENGLISH PROPER NOUNS INTO ARABIC}

YOWELL Y. AZIZ

\section{INTRODUCTION}

\section{1. What Is Transliteration?}

"In transliteration," writes J.C. Catford (1965), p. 66) in his Linguistic Theory of Translation, "SL(source language) graphological units are replaced by TL (target language) graphological units." He explains this process by setting up the following three steps:

(a) Letters of the source language are replaced by sounds of the source language.

(b) The sounds of the source language are translated into sounds of the target language.

(c) The sounds of the target language are replaced by letters of the target language.

It is to be noted that Catford starts and ends with the written form of the word. The implication is that transliteration is basically concerned with writing, i.e., the final product is the written word. Step (a) however is not necessary, since transliteration can have the oral medium as its starting point. Moreover, although in the case of modern living languages, transliteration is generally based on the spoken form, in ancient languages it is the usual practice to transcibe letter for letter, since the precise phonetic value of some letters may not be knwon (Nida, 1964, p. 193).

1. 2. Transliteration and graphological translation.

Step (b) above shows that the basis of transliteration is the phonetic substance, in that it is the sound and not the shape of the letter which is translated. The process in which the shape of the letter is translated is termed graphological translation (Catford, 1965, pp. 62-65). Thus the main difference between transliteration and graphological translation lies in the fact that "equivalence" in the former is based on sounds, in the latter on the shape of the letter. The following example will illustrate the point.
Original
Graphological translation
رجA Transliteration
RA JUL

Graphological translation is difficult because graphological equivalences among different systems of writing are not common. Its uses are restricted and highly specialized : its main attraction lies in its exotic flavour, which is 
sometimes exploited by typographers and penmen. Transliteration, on the other hand, is very common; it is the usual process of writing borrowed words.

\subsection{Transliteration of Proper Nouns}

All types of words may be borrowed. But by far the most common type of transliteration is that of proper nouns. This is hardly surprising since such nouns must usually be borrowed.

Transliteration of proper nouns may be found in all types of writing, although it occurs most frequently in works of translation. Hence it is considered part of translation.

\subsection{Aim and plan of this study}

Nowadays translation, and consequently transliteration, has acquired special importance in the Arab World. Several Arab countries including Iraq have embarked on the enormous process of arabicization, i.e., using the national language, Arabic, as the medium of instruction and expression for all branches of learning, especially science and technology. Translation, the bulk of which is done from English, forms an important part of this process. Among the most frequent problems of translation are those of transliteration of foreign proper nouns.

The present study is mainly concerned with transliteration of English proper nouns into Arabic. It begins with a brief historical note on transliteration as was practiced by ancient Arab writers; then it examines the main difficulties of transcribing English proper nouns into Arabic and concludes by offering some practical suggestions for solving them. Although the main concern of this study is transliteration of English proper nouns, it is hoped that it will have a bearing on transliteration of foreign nouns into Arabic in general.

\section{HISTORICAL BACKGROUND}

It is generally agreed that translation into Arabic flourished during the Abbasid Dynasty and had its golden age during the rule of al-Ma'mun (813-883). Most of these translations were done from Greek, Persian, Sanskrit and Syriac, often indirectly through the last language. As a result of these activities, many words, including a considerable number of proper nouns, were introduced into Arabic.

A detailed and comprehensive study of the methods of transliteration used by ancient Arabic writers is yet to be attempted. However, such a study is outside the scope of this paper. Here a brief and illustrative summary of some aspects of ancient transliteration will be attempted. Both the foreign and the Arabic words will be mentioned to illustrate the point. However, it is often difficult to ascertain whether the word was borrowed directly or indirectly into Arabic. Moreover, in the case of ancient languages it is not always easy to know the exact sound quality of every letter. Hence orthographical rather than phonetic symbols are used. For practical considerations Latin letters are chosen to transcribe the borrowed word. 
The sound represented by the Latin letter $\mathrm{g}$ was often rendered into Arabic by $\dot{\varepsilon}$, e.g. Pythagoras فيثشا غورس But sometimes it was also written $₹$, e.g. Galenus جسالـينوس(Ma'luf, 1933, pp. 145-146).

The Latin letter c and its Greek equivalent were usually transcribed 3 , e.g. Centaurium ق.نطاريون. It was also rendered as كوندون. Thus Macedonia was

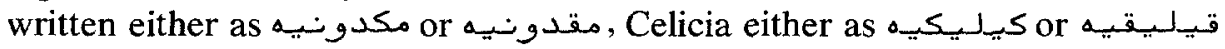
(Ma'lif, 1933, p. 147; Shahabi, 1964, p. 360).

The letter $t$ was rendered into Arabic by its emphatic Arabic "equivalent"

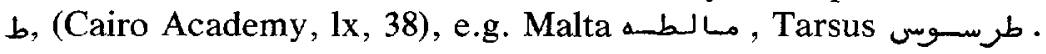

The letters th $|\theta|$ and $d$ were written in Arabic as $\ddot{\sim}$ and ; and sometimes

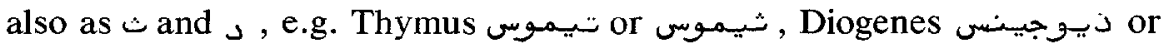
ديـوجينس ث (Ma'luf, 1933, p. 147).

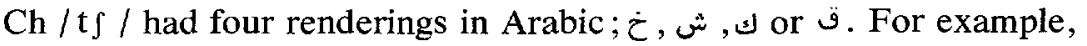
Achilles, Archimedeus, Antioch and Chrones were written as ارخميدس , اخيل ف قترن Ma'luf, 1933 p. 150).

The letter $\mathrm{h}$ was transcribed either as $\rightarrow$ or $\mathrm{l}$. Thus Homerus was written

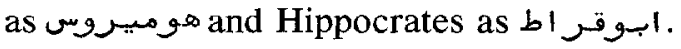

The letter p was transcribed as ف or ب (Cairo Academy, 111, 32); e.g. Pythagoras فيثنا غورس and Hippocrates ابوقتر اط

Little is known of transliteration of vowel sounds into Arabic. One reason for this is that short vowels are not represented in the written form of the word in Arabic : only long vowels (or rather semivowels) have graphological symbols. However, we do know that the Greek letter $Y$ was often written as $g$, but sometimes also as s e.g. Pyrites بوري_طس and Chymus The letter a

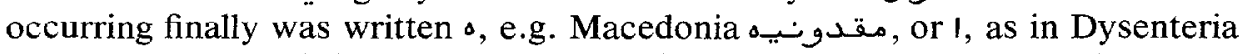
دوسيـنطاريـ (Ma'luf, 1933, p. 149). The letters $a o$ and $a$ were sometimes transcribed lor 1 , e.g. Laodicea اللاذقيـ, Ascalon عسيـقلان, Cairo Academy, $1 \mathrm{v}, 34)$.

A glance at the above examples will show that (a) transliteration in ancient Arabic writings was not always consistent, (b) the foreign word was often radically readjusted to fit in the sound pattern of Arabic, (c) readjustment was not confined to sounds which did not exist in Arabic but extended to those which did exist in the language and (d) readjustment did not stop at the level of individual sounds but involved the whole word.

\section{IMPORTANCE OF TRANSLITERATION OF PROPER NOUNS}

In transliteration, as in translation, it is nearly impossible to reproduce the exact equivalent of the original word owing to the numerous phonological and graphological differences among languages. Thus all that one hopes for is approximation, which involves readjustment of the original word to the sound and writing pattern of the target language. Readjustment usually becomes more urgent and its problems more serious when transliteration is carried out between remotely related or unrelated languages, like English (an Indo-European language) and Arabic (a Semitic language). 
Problems of transliteration can be so serious that they may interfere with meaning and thus confuse the reader, as is illustrated by the following authentic incident ${ }^{1}$.

Translator (who has just finished translating a novel and given it to his friend to read) : How do you like the novel?

His friend: Disgusting. You know I don't enjoy reading stories about queer people.

Translator: What queer people? I don't understand.

His friend: I threw the book away after reading the first two pages.

Translator: Why? There are no queer persons in the book. The characters are all decent ordinary people like you and me.

His friend : Decent ordinary people! Listen to this. (He quotes)

(Kanat Margaret mughramatan bibawl zawjiha) ${ }^{2}$

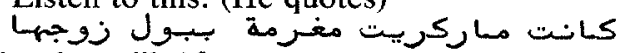

Translator (Laughing and correcting him) :

(Kanat Margaret mughramatan bi Paul zawjiha) ${ }^{3}$

$$
\text { كLانت مساركريت مغرمة بــ برل زوجهيا }
$$

In that short incident the transliteration of the personal name Paul created three problems which played havoc with the meaning of the sentence. These problems are : capitalization, the transliteration of $P$ and the prepositional prefix

All these will be discussed in greater detail later. Here a brief explanation will be sufficient. The absence of capitalization from Arabic and the lack of a graphological equivalent of $P$ resulted in the reader's confusing the proper noun Paul, written بول, with the ordinary word of the same spelling. This tendency was further encouraged by prefixing the prepositional - to the word.

Thus vague or incorrect transliteration of proper nouns may lead to wrong phonological realization of the word, which may in turn mislead the reader.

\section{PROBLEMS OF TRANSLITERATION OF ENGLISH PROPER NOUNS}

Problems of transliterating English proper nouns into Arabic may be divided into the following three main classes:

(a) Phonological-graphological problems.

(b) Graphological problems.

(c) Other problems

\subsection{Phonological-graphological problems}

Transliteration of English proper nouns into Arabic often involves readjustment of the original word to the phonological and graphological patterns of the target language. In this section the main problems of this readjustment will be discussed with regard to (a) consonants and (b) vowels and diphtongs. Since our main concern here is tranliteration, graphological symbols will be used to represent both the sound and the written form of the letter, and phonetic symbols will be used only when they are necessary.

1. I owe this story to my colleague Dr Issan Al-Khatib.

2. Margaret was fond of her husband's urine.

3. Margaret was fond of her husband, Paul. 


\subsubsection{Consonants}

For the sake of this study four kinds of English consonants may be distinguished :

(a) English consonants which have equivalents or approximate equivalents in Arabic. These usually pose no problems for translators. The following table shows the English consonants and their Arabic equivalents.

\begin{tabular}{|c|c|c|c|}
\hline English & Arabic & English & Arabic \\
\hline b & $\varphi$ & $\mathrm{c}, \mathrm{k}, \mathrm{q}$ & ك \\
\hline d & د. & $s, c|c|$ & سu \\
\hline 1 & J & $\mathrm{j}$ & ج \\
\hline $\mathrm{m}$ & $p$ & $r$ & 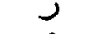 \\
\hline $\mathrm{n}$ & ن & w & 9 \\
\hline $\operatorname{sh} / 5 /$ & $\hat{~}$ & $y$ & ي \\
\hline th $|\theta|$ & $ث$ & z & j \\
\hline$|\alpha|$ & & & \\
\hline
\end{tabular}

(b) English consonants which have no graphological equivalent in Arabic. Considerable inconsistency is found in rendering these consonants; either a new letter or the nearest equivalent is used.

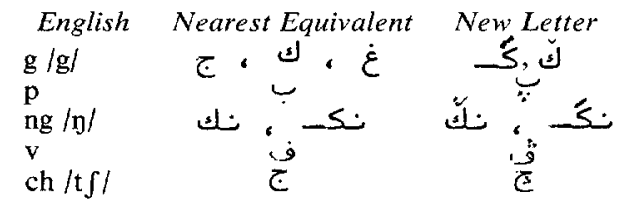

(c) Two English consonants $t$ and $s$ pose special problems in transliteration despite the fact that they do have equivalents in Arabic. The problem here is that each of those two sounds has an emphatic partner which is represented by a separate graphological symbol. Thus $t$ is transliterated either as $\ddot{O}$ or as the emphatic b; and $s$ is rendered either by $w$ or by its emphatic partner $\omega$.

An additional complication is presented by $s$ when pronounced $/ z /$. Here the translator sometimes follows the sound of the letter, but more often he transcribes the written form. Hence the English $s$ is represented by either w or j.

(d) Unpronounced letters. Since transliteration is normally based on phonology, unpronounced letters of the source language are dropped in the target language. However, there is one noticeable exception to this general rule, namely the "silent" $r$. This letter even when it is unpronounced in English, usually appears in Arabic transliteration. Here again transliteration seems to be based on the written form, and the tendency is encouraged by the fact that Arabs speaking English usually pronounce the "silent" $r$.

\subsubsection{Vowels and Diphthongs}

Problems of transliterating English vowels and diphthongs into Arabic are more complicated than those of consonants. There are two reasons for this. First, the two languages reveal greater and subtler divergences with regard to this aspect of their phonological systems. Secondly, an additional difficulty is posed by the fact that Arabic script is basically syllabic. Each letter represents a specific consonant. Vowels are indicated by three diacritic marks above or 
below the consonant $: \geqslant$, and $\geq$. These diacritic marks are normally omitted in ordinary everyday practice owing to printing difficulties. Thus the first major problem faced by a translator is how to render English vowels and diphthongs into Arabic. Should he use diacritic marks? But he is not free here; this choice is decided for him by the printer. The other alternative is to make use of $\geqslant, \geq$ and $Z$ which represent semi-vowels and are approximately equivalent to the English $/ \mathrm{i}: /, / \mathrm{u}: /$ and $/ \Re /$. If he opts for this second alternative his main problem would be how to render a total number of about 21 English vowels and diphthongs into Arabic by using only three graphological symbols. The following brief survey will show how each of the 12 English vowels and the 9 diphthongs are usually transliterated into Arabic.

A. Vowels

(a) The following vowels are more or less adequately rendered into

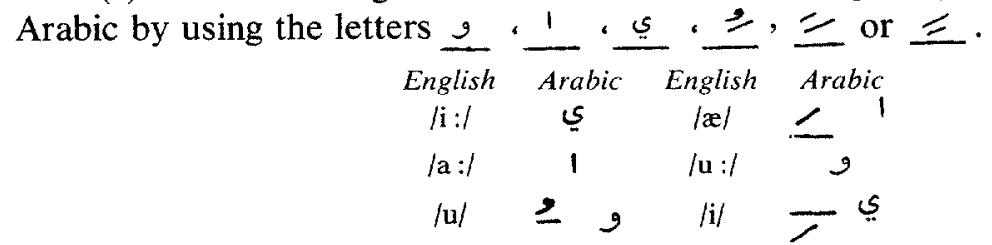

(b) The following vowels are readjusted to fit the target language, and are rendered into Arabic either by using 2,1 , and $ي$ or the diacritic marks, as shown in the table.

B. Diphthongs

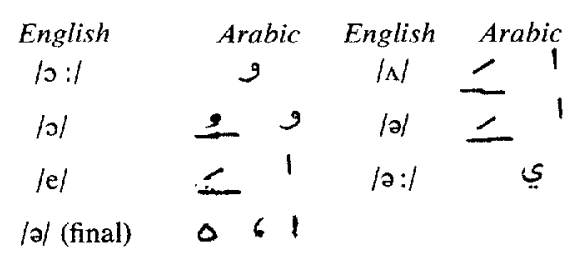

(a) The following English diphthongs are more or less adequately rendered into Arabic by using combinations of the letters 9.1 . and ي

\begin{tabular}{|c|c|c|c|}
\hline $\begin{array}{c}\text { English } \\
\quad \text { /ai/ }\end{array}$ & $\begin{array}{c}\text { Arabic } \\
\text { اي }\end{array}$ & $\begin{array}{c}\text { English } \\
\quad / \mathrm{au} /\end{array}$ & $\begin{array}{c}\text { Arabic } \\
g^{1}\end{array}$ \\
\hline $\mid \mathrm{bi} /$ & وي & /io/ & ، بيــا \\
\hline
\end{tabular}

(b) The remaining five English diphthongs are usually monophthongized when rendered into Arabic, and are often transliterated by using the letters 9.1 and $ي$. Considerable readjustment is required here.

$\begin{array}{cccc}\text { English } & \text { Arabic } & \text { English } & \text { Arabic } \\ \text { /ei/ } & \mathrm{s} / \mathrm{i}: / & \text { lou/ } & \mathrm{g} / \mathrm{u}: / \\ \text { /ea/ } & \mathrm{I} / \mathrm{lal} & \text { lod } & \mathrm{g} / \mathrm{u}: / \\ \text { /u/ } & \mathrm{g} / \mathrm{u}: / & & \end{array}$


META, XXVIII, 1

\subsection{Graphological Problems}

Two types of graphological problems may be recognized here : (a) Capitalization and (b) Prefixing.

\subsubsection{Capitalization}

Proper nouns in English are distinguished from other words by initial capitals. This is a valuable graphological practice, which guides the reader to the correct path. Unfortunately, capitalization does not exist in Arabic, and the reader relies on his general knowledge and linguistic intuition in guessing whether a word is proper noun or not. This is true of Arabic and non-Arabic nouns. However, the act of guessing becomes more complicated and less reliable in the case of borrowed words. Translators, and writers in general, tackle this problem in different ways. Among the signs used to distinguish proper nouns are : brackets ( ), double inverted commas " ", single inverted commas ' ', and even underlining. In addition, the proper noun is sometimes added to the text in Latin letters. As the foreign proper noun is gradually adopted into the language and becomes part of it, these distinguishing marks are left out.

Some translators think these distinguishing marks are awkward and unnecessary; they never use them.

\subsubsection{Prefixing}

The problem of capitalization, or rather absence of capitalization, in Arabic is complicated by two of the common prepositional prefixes, which are attached to nouns, including proper nouns; namely, _ and In foreign proper nouns written between brackets or inverted commas these prefixes pose some difficulty. They are either written outside the 'markers' and thus separated from the noun, which is regarded by many as awkward and unnatural; or more often placed inside the 'markers' and attached to the noun. The latter practice sometimes misleads the reader into thinking that the preposition is part of the noun. Here is an authentic example taken from a translation by the present writer, where Grub Street occurred in the sentence :

لكان لكرب ستريت وجود حقيقي in which the translation was to be published thought that one word, subject of 0 iL and the sentence was corrected accordingly : كان لكرب ستريت، وجود ا حقيتقيـا Admittedly the problem of the prefix = in this example did not affect the meaning seriously; but it undermined the grammatical structure of the sentence.

However, in some examples the problem of prefixing may interfere with the meaning of the sentence as in لانفرنس ميناء كبير جميل 'Inverness has a big beautiful harbour.' If the proper noun and the preposition were taken as one word, the sentence would mean 'Inverness is a big beautiful port.'

Problems arising from a tendency in the opposite direction are also attested, although they are probably less common. These concern proper

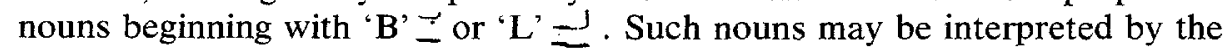
Arabic reader as made up of a prepositional prefix and a noun. For example, 
'Then Leonard sent the letter' would mean' Then he

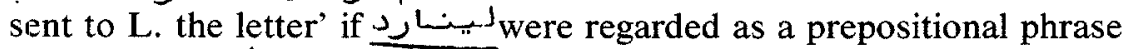
composed of $\_$and $\underline{\mathrm{J}} \mathrm{J}$.

\subsection{Other problems}

Three types of problems are discussed here: (a) proper noun initials (b) traditional proper nouns and (c) transliteration versus translation of proper nouns.

\subsubsection{Proper noun initials}

In transliteration of proper noun initials translaters often follow spelling, and the Latin letter is replaced by its 'equivalent' or nearest 'equivalent' in Arabic. Thus D.H. Lawrence is transliterated and A.B. Patterson إب • بـاتربن

This practice poses three main problems. First, as is well known, some English letters have no equivalents in Arabic, e.g. P. V and G. They are usually transcribed as $\_, \omega_{-}$and $\sqrt{\varepsilon}$, which are used to render $\mathrm{B}, \mathrm{F}$ and $\mathrm{K}$ as well. Secondly, sometimes more than one initial is represented by a single Arabic

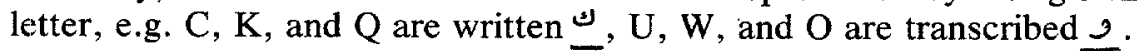
Thus useful distinctions are lost. Finally in letters which have two spoken realizations, e.g. C $/ \mathrm{k} /$ or $/ \mathrm{s} /, \mathrm{G} / \mathrm{g} /$ or $/ \mathrm{d} /$, these translators try to draw a distinction by using two different Arabic letters chosen on a phonetic basis. Thus $\mathrm{C} / \mathrm{k} /$ is translitereated $s$ and $\mathrm{C} / \mathrm{s} / \mathrm{\omega}$. The difficulty here is that it is not always easy to find out the full name represented by the initial letter. Thus determining the phonetic value of some initials becomes problematic.

For these reasons some translators prefer to transcribe the name of the initial. For example, D. H. Lawrence and A. B. Patterson are written as

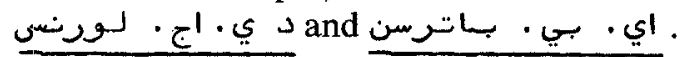

Thus, at present, inconsistency seems to be the rule in transliterating initials, a fact which is attested not only in works by different translators but by the same person.

\subsubsection{Traditional proper nouns}

The term Traditional proper noun is used to denote all foreign proper nouns which were borrowed into Arabic during the various periods of its long history up to the beginning of the Modern Arab Awakening, usually dated from the end of the eighteenth century. Translators sometimes borrow these nouns موسيس , دي اود

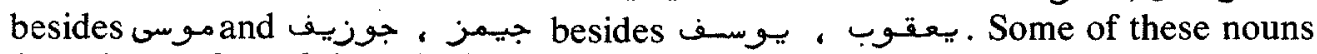
have been adopted into the language as personal names quite independently.

The dilemma which a translator faces when dealing with these nouns is whether to choose the traditional form or the modern form. Should he write

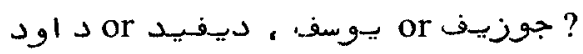

Sometimes the traditional name is so established and widespread that it is preferred to the modern foreign form. Thus we nearly always write

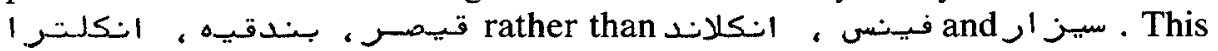
tendency is probably more common in transliteration of geographical names. 
In personal names and names of literary characters, the trend is in the other direction : the modern form is preferred to the older one. Thus Tobias, Tom Jones and Joseph Andrews are usually transcribed as ت توريسايساس

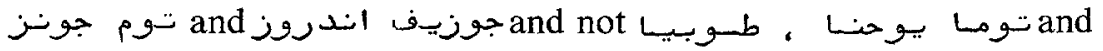
• يوسف اندريهوس تونز

\subsubsection{Transliteration versus translation}

Proper nouns are usually borrowed into the target language : but there are exceptions. Some types of proper nouns are translated rather than transliterated.

The following types of proper nouns may be recognized here.

(1) Personal names with titles (Mr Hill) and without titles (Jack Nelson).

(2) Geographical names, which include names of the continents, countries, states, rivers, lakes, etc.

(3) Temporal names, including names of the months, the days of the week and festivals.

(4) Names of publications, including titles of books, newspapers and journals.

\subsubsection{Personal names}

The general practice with proper nouns used as personal names is to adopt them as they are rather than translate them. However, a slight difficulty arises with titles, e.g. Mr, Mrs, Professor, Miss and Marshal. Should the title be kept as it is or replaced by its Arabic equivalent? Some translators prefer

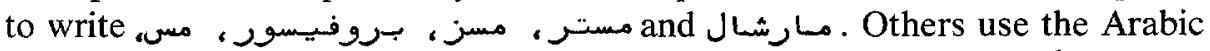
translation of these titles : المشير and السسيد، السيدة ، الاستبـاذ ،

However, no such difficulty arises with some titles, including King, President, Sergeant and Judge, which are usually replaced by their Arabic

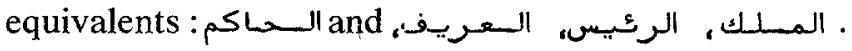

\subsubsection{Geographical names}

Names of the continents, countries, cities and oceans usually pose no problems since they have established Arabic equivalents. Thus Europe, Scotland

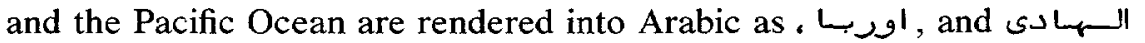

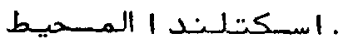

There is however some disagreement among translators concerning less well-known geographical names. For example, Camp David is transliterated as كامب ديففيد in Iraqi mass media; but is replaced by its translation equivalent مخيم د داود in Syrian newspapers and broadcasting station.

\subsubsection{Temporal Names}

What has been said of geographical names is basically also true of temporal names. Thus names of the days of the week, the months, the seasons and the well-known festivals (Christmas, New Year, Easter) all have Arabic equivalents. Any inconsistency which might be found here concerns temporal names which are not so well-known, such as local festivals which have no Arabic equivalents. Thus Boxing Day, for instance, appears either as بـ or • يوم تقديم الهيد ايسا 


\subsubsection{Names of Publications}

Custom varies considerably with regard to writing names of publications. With newspapers and magazines, the general practice seems to favour borrowing these names direct into the target language. For example, The Economist, The Observer, Time, Newsweek and The Times are usually transliterated into Arabic as نيوزويك ، تسايم ، اوبزيرفر , اكونومستر and ت. ت.

Titles of literary and scientific works, on the other hand, are normally replaced by their translation equivalents, except of course when such titles denote personal names (see Personal Names above). Thus, The Merchant of Venice, Paradise Lost and An Introduction to General Physics appear as مقدمة في الفيـزيـاء العـامة and الــفردوس المفقود, تـاجر البـندقيـة

The problem with translation equivalents is that some titles appear in more than one version. For examples, Much Ado About Nothing is rendered into

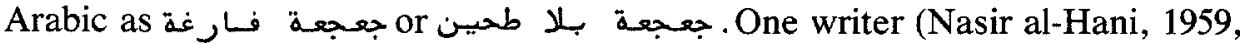
pp. 41 \& 94) has two versions for Shakespeare's Midsummer Night's Dream

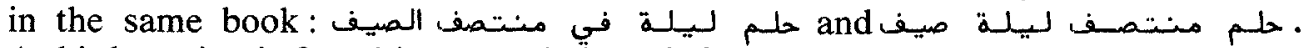
A third version is found in a translation of Ifor Evan's Short History of English Literature by Shawqi al-Sukkari and Abdulla Hafiz, who use حلـم لـيلـة صسيف Similarly, Arnold Bennett's The Old Wives Tale has at least two translations :

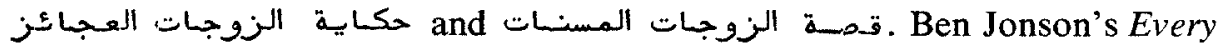

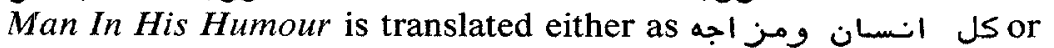

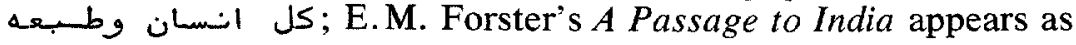

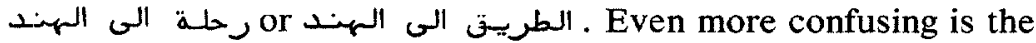
title of Lyrical Ballads in Arabic, which is rendered either as . قصسائد قصسصسية غنـائية الحكايسات الوجد انسية المنظوهة

A few translators prefer to borrow titles of literary works into the target language, especially Latin titles. Thus, one comes across Dryden's Religio Medici, for instance, trascribed as ريبليجيو مد يكي.

\section{SOLUTIONS AND SUGGESTIONS}

This section will be divided into two parts : the first part will be devoted to reviewing major efforts both by individuals and organizations to solve some of the problems of transliteration discussed in this study. In the second part, practical suggestions will be put forward to deal with difficulties of transliteration, especially those which have formerly received relatively little attention.

\subsection{Previous Attempts To Solve Transliteration Problems}

In modern time, the problem of transliteration of foreign proper nouns into Arabic was felt as early as the beginning of this century. In 1911 Amin Basha al-Ma'luf published an article, تعبريب الاسماء الاعجمية 'Arabicization of Foreign Proper Nouns', in the June and July issues of the Egyptian journal al-Muqtataf.The article reappeared twenty-two years later in the February issue of the same journal (pp. 144-151). Al-Ma'luf confined his attention to transliteration of proper nouns derived from Latin and Greek, and concentrated 
mainly on problems of writing certain consonants, including $g, d, t h, c, j, h, v$, and $c h$. His advice to the modern Arabic translator was to follow the practice of ancient Arabic writers.

This advice, if followed, will pose three major problems. First, it is surely too much to expect from the translator to recognize the Latin or Greek origin of every word he is to transcribe. Secondly, the ancient Arabic writer was not always consistent in his transliteration methods (see Historical Background). Finally, some of the ancient practices are no longer suitable, as was pointed out by the Academy of Cairo (xvl, 1963, p. 63); rendering $T$ as $b$ and $C$ and $K$ as . In spite of these and other drawbacks, Ma'luf's article made valuable contributions to the subject.

Similar points concerning transliteration of foreign proper nouns were raised by Ahmad Issa in his التهذيب في اهسول التعريب, Useful Principles of Transliteration Into Arabic, which was published in Cairo in 1923.

Among learned organizations which interested themselves in the subject, the efforts of the Academy of Cairo are worth mentioning. As early as 1936 a special committee was formed by the Academy to study the problem of writing 'ancient Latin and Greek proper names in Arabic letters' (lv, 1937, p. 31). In formulating its decisions, The Committee took into consideration the methods of transliteration followed by ancient Arab translators in the East, and made use of the two studies mentioned above (lv, 1937, pp. 31-32). The rules set up by the Committee were more comprehensive and included a number of consonants and vowels which had not been discussed before. However, it was basically not much different from the two previous ones, in that it was confined to Latin and Greek proper nouns, and its suggested solutions were inspired by ancient Arabic translators.

Twenty-seven years later, the Academy of Cairo found it necessary to take up the subject again, and a new committee, لبسنة اللهجبات 'The Committee of Dialects' was authorized to look into the matter. Its resolutions were published in the Academy's Review in 1963 (xvl, pp. 83-85). Since they are the most up-to-date guidelines formulated by an authorized official organization which commands considerable influence and respect in the Arab World, the relevant parts of these resolutions are worth quoting in full.

1. Rules of transliteration are to be applied to personal and geographical names as well as to scientific terms.

2. Foreign proper nouns are to be transliterated as they are pronounced by the native speaker.

3. Traditional foreign proper nouns which have become established in Arabic are not subject to the rules stated here.

4. Foreign proper nouns should be written between brackets until they have become established in Arabic.

5. It is not necessary to invent new Arabic letters to transcribe foreign words, except in the following three instances : $G, P$ and $\mathrm{V}$, which should be written $s, C$ and $i$ respectively.

6. Silent letters should not be represented in Arabic. 
7. The following table will show how some of the consonants may be transcribed into Arabic.

\begin{tabular}{|c|c|c|c|}
\hline Foreig & Consonant & Arabic $\mathrm{Tr}$ & Transliteration \\
\hline & $\mathrm{C}$ & سي & ك . \\
\hline & $\mathrm{Ch}$ & & تشى \\
\hline & $\mathbf{H}$ & & $\rightarrow$ \\
\hline & $\mathbf{J}$ & & $\tau$ \\
\hline & $\mathrm{K}$ & & ك \\
\hline ' & $\mathrm{Ph}$ & & ف \\
\hline & $Q$ & & ك5 \\
\hline & $\mathrm{T}$ & & $\ddot{*}$ \\
\hline & Th & j. & ، \\
\hline & $\mathrm{W}$ & 。 & . 9 \\
\hline & $\mathbf{Z}$ & ، تزز & 'j \\
\hline
\end{tabular}

8. Vowels are on the whole more difficult to transliterate, and should be written as they are pronounced in the original language. (a) Short vowels are to be represented by the Arabic short vowels $\geq,-$, and $\geq$. Medium and long vowels may be represented by the letters 9 , $\mathbf{\text { and }} I$, which may also be used to render short vowels in words of few syllables. (b) Long vowels which have no equivalents in Arabic are to be represented by their nearest equivalents. (c) The vowels $/ 0: /$ and $/ 0 /$ are to be transcribed as '_ and 'g respectively. (d) Initial vowels should be rendered by 1 or 7 in accordance with the pronunciation of the foreign proper noun. (e) Initial consonant cluster should be separated by inserting a suitable vowel. (f) Final vowels /a/ and /a/ are to be transcribed o and I respectively. (g) The definite article الـ must not be used with proper nouns except where the use of the article with proper nouns has become established.

\subsection{Comments and suggestions}

These rules are intended to be applied to foreign proper nouns in general; nevertheless, they contain valuable guidelines which may be used by translators to deal with some of the problems pointed out in this study, especially phonological-graphological problems.

Rule 4 is not a very practical way of distinguishing a foreign proper noun. What is our criterion for judging that a foreign proper noun has become established in the target language? What is actually required here is a practical method of indicating that a certain word is proper noun - Arabic capital letters.

With regard to transliterating $C h / \mathrm{t} / \mathrm{J} /$ as , this is probably more suitable for initial position. It is not so convenient for medial and final $C h$, and certainly awkward in nouns where this sound occurs more than once, e.g. Church and Churchill. In these two positions it is better to represent $C h$ by $ش, \tau$ or even r. The last two being the nearest equivalents to the English sound, deserve to have priority over the others.

Rule 6 dealing with silent letters is basically valid, except in the case of $r$, where pronunciation is governed by the type of Standard English and the 
position of this letter. Thus, the $r$ in Peter, for instance, is not pronounced in RP (Received Pronunciation) when followed by a consonant sound, but it is pronounced before a vowel sound. However, it is always pronounced in other varieties of Standard English (e.g. Scottish and American). In the interest of simplicity and consistency, it is better this letter were always rendered into Arabic by its equivalent $J$.

Nothing is said about the sound represented by $n g / \mathrm{y} /$ and $s$. The first does not exist in Arabic. Its nearest approximate equivalent would be the letters $\_$. The oral realization of $s$ is predictable since it is governed by certain rules. It is pronounced $\mid \mathrm{z} /, / \mathrm{iz} /$ or $/ \mathrm{s} /$ depending on whether it is followed by a voiced, a sibilant or a voiceless sound. Subject to these rules, $s$ may be transcribed either as $j$ or $w$. The choice between $w$ and $\omega$ should be determined by the phonetic rules of Arabic. If this proves too complicated, $\sim$ may be dropped in favour of $\omega$, which is often nearer to the English sound.

The Committee rightly states that vowels are more difficult to render into Arabic than consonants. The main reason for this is that the two languages show marked differences with regard to their vowel systems. The Arabic translator has limited resources at his disposal to overcome this difficulty: he has to use $1, y$ and $s$, sometimes in combination with $\_,-\infty$ and - to express the various English vowels and diphthongs. Thus /ai/ may be transliterated as

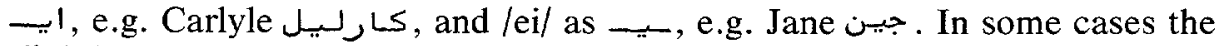
diphthong is monophthongized in Arabic, e.g. Moore مون (see also Diphthongs above).

One of the graphological problems, capitalization, has already been discussed. The other problem, prefixing, is closely connected with the first one. The prepositions $\longrightarrow$ and $\_$should be separated from the proper noun and preferably written in their final forms, $4, J$, if confusion were to be avoided completely.

In transliterating personal name initials, there are two good reasons for choosing the name of the initial rather than transcribe its sound or spelling. First, it will solve the problem of finding the exact phonetic or orthographical equivalent, which may not exist in the target language. Secondly, in real life it is the name of the initial which is used and not its sound. Thus, W.S. Hill, for instance, is usually called دبـلـيـ . اس. sيل . To show that the first two words are initials a full stop may be used after each of them.

The problem of traditional personal names is more complicated. A simple solution would be to transcribe personal names as they are pronounced by the native speaker, except in the case of 'biblical' names whose Arabic equivalents have become established. For example, David would be written ديففيد, except when it refers to 'historical' names (e.g. King David), in which case it should be transcribed د أود 'In the same way a distinction could be drawn between

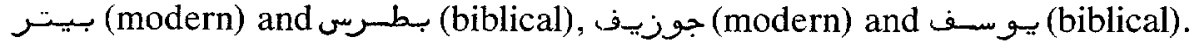

Most geographical and temporal names have established Arabic equivalents, which should be preferred to other forms in transliteration. If however the proper name has no Arabic equivalent, then there is no reason why borrowing should not be preferred to translation, since the former is the easier 
and the more usual process. Admittedly, we have established translations like

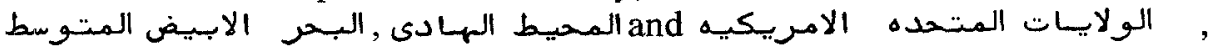
but they are few compared with borrowed proper names. Moreover, direct borrowing seems to be more productive nowadays. Thus Little Rock and New نيوزيلـنده and لنتل روك Zealand, for instance, are nearly always written as

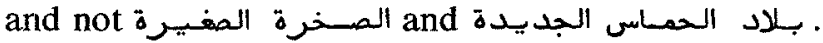

Titles of personal names may be divided into : (a) those which have Arabic equivalents, and (b) those for which no equivalent exists in Arabic. The first type includes, Princess, Prince, Father, President, Mrs and Mr. There is no reason why these should not be replaced by their Arabic equivalents :

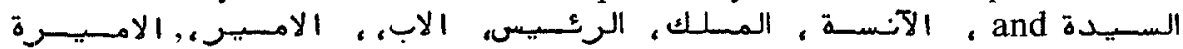
. Examples of the second type are : Count, Lord, Baron and Viscount. These are usually borrowed into the target language. A third group may be recognized for which there are modified Arabic forms; e.g. Duke دوق Duchess دوقة, and Countess كونتسة.

\section{CONCLUSION}

Transliteration of English proper nouns - indeed, of foreign proper nouns in general - is at present characterized by inconsistency, which often results in misunderstanding and confusion. The main reason for this seems to be the fact that not enough attention is paid to this important aspect of translation. Translators often regard transliteration of foreign proper nouns as an unimportant part of their task, which does not merit much thinking. Thus their efforts in this respect are characterized by being whimsical and haphazard. The few studies that appear occasionally are confined to the pages of journals or are kept in the files of the language academy. Their impact on the great number of persons actually engaged in translation is negligible.

It should be admitted that many problems discussed in this paper are of complex nature, for which no easy solutions are possible. However, it would be useful for the translator to remember these general points.

(1) Transliteration does not mean reproducing the exact copy of the original, but the nearest equivalent.

(2) Vague and imprecise transliteration may interfere with meaning; it should therefore be avoided.

(3) It is better to be both consistent and correct; but of the two the former is more important in the process of transliteration.

(4) Established forms should have priority over new ones, even if the latter were more correct.

(5) In a language like Arabic with a long written tradition, radical changes in the way of writing should be kept to the minimum and resorted to only when they are absolutely necessary if such changes were to be accepted by the general public.

\section{REFERENCES}

Catford, J.C. (1965) : A Linguistic Theory of Translation, London, Oxford University Press. Hani, Nasir (1959) : Min Istilahat al-Adab al-Gharbi, Cairo, Dar al-Ma'arif. 
'Kitabat al-A'lam al-A'jamiya bi Huruf Arabiya' (1963): Majalat Majma' al-Lugha al-Arabiya bi al-qahira.

Ma'luf, Amin (1933): 'Ta'rib al-Asma' al-Ajamiya', Al-Muqtataf.

Nida, Eugene, A. (1964): Toward A Science of Translating, Leiden, E.J. Brill.

'Quararat Fi Kitabat al-A'lam al-Yunaniya Wa al-Latiniya bi Huruf Arabiya' (1936) Majalat Majma' al-Lugha al-Arabiya bi al-Qahira. 